\title{
Transformation Path of International Trade Model under Low Carbon Economy Environment
}

\author{
Tao Wan \\ Wuhan Business University, School of Economics and Finance, Wuhan, Hubei, 430056
}

Keywords: international trade model; low carbon economy; transformation path

\begin{abstract}
The low-carbon economy will have a profound impact on international trade. With the rapid rise of the low-carbon economy around the world, the international trade pattern will undergo major adjustments; low-carbon economy will innovate carbon finance, and further expand connotation of international service trade; low-carbon economy will promote a new round of technological revolution, promote competition and cooperation in international technology trade and technology transfer; potential conflicts between unilateral trade measures related to low-carbon economy and multilateral trade rules may become new trade barriers.
\end{abstract}

\section{Introduction}

The various ecological problems brought about by global warming have seriously threatened the survival and development of mankind. Therefore, at the Copenhagen conference, the concept of a low-carbon economy was officially proposed for the first time, and the low-carbon economy was gradually promoted on a global scale. In the field of international trade, people have also begun to introduce the concept of low-carbon economy, which has spawned new trade rules, especially for some high-energy and high-pollution products. China is a big trading country, China's economic transformation has not yet been completed, and the concept of a low-carbon economy will have a greater impact on China's international trade. This requires Chinese enterprises to cater to the development concept of low-carbon economy as soon as possible, adjust their own trade strategies, and develop low-carbon technologies, so as to obtain higher market competitiveness in international trade by virtue of technology and quality.

\section{Background and Methods of International Trade Rules}

Achieving the development of the international carbon trading market in the direction of standardization is the main purpose of the carbon trading mechanism. In essence, carbon assets are not in the category of commodities, so there is no development value. However, in order to optimize the energy structure and make full use of energy to develop advanced energy technologies and invest in production, Western developed countries have increased the difficulty of greenhouse gas emissions and increased costs. For developing countries, carbon energy application efficiency is low, and there is sufficient space for emission reduction, but the cost is low, which leads to different costs and price differences before the same emission. In this context, the emissions of developing countries are consistent with the gas emission requirements of developed countries, thus building a carbon trading market. In the Kyoto Protocol, there are three carbon trading mechanisms, namely, joint implementation, emissions trading and clean development mechanism.

There are three main forms of international trade rules: one is proposed by the hegemonic state. The international trade rules proposed by hegemonic countries are based on their own interests in order to seek more economic benefits. In this kind of international trade relationship, hegemonic countries do not pay attention to the interests of small and weak countries. Second, the developed countries jointly formulated. The developed countries communicated with each other and adopted the cooperation model to propose international trade rules. Third, international organizations develop international trade rules. 


\section{The Impact of Low-carbon Economy on International Trade Patterns and Rules}

Since the low-carbon economy is a relatively new concept, it has not been able to form a more unified understanding so far. Nevertheless, we can still give a definition based on the opinions of most scholars. Low-carbon economy refers to the economic development model of low energy consumption, low pollution and low emissions. It is a major change and progress of human agricultural civilization and industrial civilization. Its essence is to develop high-efficiency energy, clean energy and green GDP, and pass energy. Technology, emission reduction technologies, etc. to achieve the fundamental transformation of industrial structure innovation and economic development system. Therefore, it has an important impact on the existing international trade patterns and rules, as follows.

Since the low-carbon economy is a relatively new concept, it has not been able to form a more unified understanding so far. Nevertheless, we can still give a definition based on the opinions of most scholars. Low-carbon economy refers to the economic development model of low energy consumption, low pollution and low emissions. It is a major change and progress of human agricultural civilization and industrial civilization. Its essence is to develop high-efficiency energy, clean energy and green GDP, and pass energy. Technology, emission reduction technologies, etc. to achieve the fundamental transformation of industrial structure innovation and economic development system. Therefore, it has an important impact on the existing international trade patterns and rules, as follows. Products, they will occupy a favorable position in international trade. For those emerging countries and developing countries, the development model of their high-carbon economy has not yet been fundamentally improved, so that they will encounter more barriers to high-carbon commodity trade in international trade and be in a competitive situation.

Under the low-carbon economic development model, a financial concept emerged, namely carbon finance. Although the definition of carbon finance has not been unified so far, the academic community is still in the definition of carbon finance. However, we can still simply define carbon finance as a financial activity related to carbon. Specifically, as long as it is to minimize all carbon financial arrangements and financial transactions, we can think of it as carbon finance, which mainly includes the trading and investment of carbon emission rights and derivatives, low carbon. Investment and financing of project development and other related financial intermediation activities. Therefore, carbon finance, as a new financial service activity, has played an active and effective role in promoting the development of a low-carbon economy, and can effectively meet the concept of a low-carbon economy to optimize the allocation of resources and reduce the cost of emissions. Therefore, we can say that the low-carbon economy has innovated the concept of carbon finance, which has further enriched and enriched the connotation of international service trade.

The concept of low-carbon economy and its promotion and implementation have given birth to a new round of technological revolution. Especially the developed countries in Europe, America and Japan have long recognized the necessity of low-carbon economy, and have adopted corresponding technological renewal and energy development. A lot of money. It should be said that they are already at the world's leading level in the low carbon economy. However, China and other emerging world countries are in a relatively weak position. The understanding and implementation of the concept of low-carbon economy still takes a long time to practice and advance, and the development and utilization and development of new energy and new environmental technologies. Compared with the country, it is at the initial stage of exploration and implementation. Therefore, developed countries have proposed to transfer new technologies to developing countries, which has promoted and promoted international technology trade and technology transfer, and there is competition and cooperation in this field of international trade.

\section{Specific Measures for China's International Trade Strategy Adjustment under Low-carbon Economy}

The low-carbon economic development model has become an inextricable topic and hot spot in international trade. As an export-oriented trade developing country, China also has an important 
responsibility that cannot be shirked. Specifically, at the International Climate Forum, China should be clear about its responsibilities and strive to win the benefits that developing countries should benefit, strengthen cooperation with developed countries, and strive to introduce and use funds and technologies from developed countries. Relevant domestic enterprises and industries have invested more funds, manpower and resources to conduct in-depth discussions and research on low-carbon economic models, effectively improve their low-carbon technology and innovation capabilities, and encourage enterprises to produce low-carbon commodities and climate-friendly commodities. In the international trade, we will seize the advantages as much as possible and grasp the initiative of international trade.

Although the carbon tariff is a new tax proposed by some developed countries, the developed countries rely on their dominant position and hegemony position in international trade, and the possibility of insisting on levying climate-related carbon tariffs is very large. of. In this case, developed countries in Europe and the United States occupy a moral high ground in the collection of carbon tariffs. Then, we must take active and effective measures to deal with carbon tariffs, rather than blindly oppose and condemn. This requires China to strengthen research on low-carbon economy. Relevant government departments should invest more manpower, material resources and financial resources to accelerate the pace of our independent innovation. Based on the development concept of low-carbon economy, we will improve energy conservation in production and consumption of our own enterprises. Emission reduction capabilities, and through these positive and effective low-carbon innovation measures to promote the healthy development of China's manufacturing and economic models. Although in the short term, the low-carbon economy has brought enormous challenges to China's economic development and international trade, in the long run, it will prompt Chinese enterprises to adjust their international trade strategies in a timely manner and strengthen international low-carbon technology and product cooperation. The government should give low-carbon technology innovation with certain policies and financial support to promote technological innovation of Chinese enterprises.

China's economic development model is mainly an extensive trade growth mode, which has already had a very serious impact and damage to China's resources and environment. Therefore, under the current international low-carbon economic concept and the background, China should adopt low-carbon measures under the moderate free trade strategy, conform to the general trend of international trade development, and better respond to low-carbon based on international trade. The new trade barriers of the economy ensure that there is still a strong and sustainable development momentum in the low-carbon economy of Chinese enterprises. Then, this requires Chinese enterprises to reduce carbon emissions in the process of trade development as much as possible, structural optimization and upgrading of foreign trade enterprises, and should vigorously develop service trade, formulate an international development strategy for service trade, and promote the process of modernization. In order to maintain a balanced development of trade in goods and services, China's international trade structure is more optimized. This will alleviate the enormous resources and environmental pressures facing China in international trade to a certain extent. In addition, China should also pay full attention to the role of enterprises in the development of low-carbon technologies and guide the independent transformation of foreign trade enterprises. This requires Chinese enterprises to strengthen environmental technology innovation based on the concept of low-carbon economy, develop environmentally friendly technologies, achieve environmental technology and theoretical innovation and management innovation, and should actively develop when participating in international trade. A variety of green products, increase the research and development of low-carbon technology, so that the road of low-carbon economic development of Chinese enterprises is not only supported by the government's macro-policy, but also allows enterprises to transform their own production and management models from within, and truly come out Continued international trade development path.

\section{Conclusion}

The development concept of low-carbon economy has promoted the reshaping of international 
trade rules, which has made Chinese enterprises face tremendous development pressure. We must seize the opportunity of a low-carbon economy and change our economic development model in a timely manner, especially from the extensive growth model to the intensive model, reduce carbon emissions, produce green products, and strive to achieve low-carbon technology innovation, so that Win opportunities for survival and development in international trade.

\section{References}

[1] $\mathrm{Li} \mathrm{Li}$. The impact of the low carbon economy on international trade rules and China's countermeasures [J]. Finance and Trade Economy, 2014(9): 114-123.

[2] Xu Hongxia, Yang Yuanyi. Thoughts on reshaping international trade rules under the low carbon economy [J]. Journal of Changsha Railway University: Social Science Edition, 2014, 27(4): 18-19.

[3] Zhou Jie, Li Jin Ye. The impact of the low carbon economy on the re-construction of international trade rules and the challenges China faces $[\mathrm{J}]$. Foreign Trade and Economics Practice, 2015, 18(10): 45-48.

[4] Guo Yukun. On the impact of low-carbon economy on international trade rules and China's countermeasures [J]. China Management Informationization, 2015 (22): 127.

[5] Ma Qun. The impact of low carbon economy on international trade development [J]. China Market, 2015 (21): 156. 